\title{
FOSSILS ARE FOR EVERYONE
}

Kramer, Jon M., Georesearch Department, Earth Museum, 3730 Toledo Ave. N., Robbinsdale, MN 55422, U.S.A.

Perhaps unlike any other field of science, paleontology is dependent upon the contributions of common everyday people. Indeed, in many cases formal academic training is completely immaterial to making great scientific discoveries in paleontology. Historically, Earth Science is replete with giants who had little or no academic background at all. In addition, the vast number of fossils in the world's institutions were discovered by amateurs and commercial collectors, not degreed professionals.

The history of commercial fossil collecting is long and honorable. It began long before the advent of geologic sciences or such things as museums. Europeans have commercially traded fossils for centuries. Before the U.S. was a nation fossils were collected and bartered by indigenous peoples that lived here. Even our founding fathers supported the fossil trade. Thomas Jefferson was a naturalist who bought and sold fossils on a regular basis.

The contributions of commercial fossil collecting have not been small. Every specimen of Archaeopteryx, arguably one of the most important fossil species known, is the result of collection by commercial groups. The largest, most complete Tyrannosaurus rex was found by a commercial party which, incidentally has discovered more $T$. rex specimens than any other group, public or private. Even Jack Horner has a commercial shop to thank for his discovery of baby dinosaurs that launched him to the front of dinosaur science. And what paleontologist today hasn't held in their hand a fossil specimen from Wards or Carolina Biological Supply during their early education? Or entered a limestone quarry, gravel pit, or coal mine to search for fossils under the auspices of the commercial owner? Who will provide those specimens or access to them if commerce in fossils is restricted?

Paleontology is best served in a spirit of working together. Cooperation between land owners and fossil collectors, government and industry, academics and amateurs, public institutions and private enterprise is all needed to the continued vitality of this science. There is no reason all concerned parties cannot work together and promote paleontology like never before. 